\title{
BF爵 EDERE
}

\author{
PÁszKa, IMre ÁGOSTON \\ paszkai@juris.u-szeged.hu \\ $\mathrm{PhD}$ Student
}

(University of Szeged, Faculty of Law and Political Sciences,

Department of International and European Law)

\section{Maritime Piracy as an International Crime in the 21st Century}

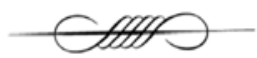

\begin{abstract}
Maritime piracy is an ancient crime which have still not disappeared and, since the mid 90s, we have been living a new golden age of piracy. According to the 2017 annual report of the International Maritime Bureau, 180 piratical incidents happened in that year. Although, piracy arised almost three decades ago, the international community only started dealing with it ten years ago on a dayto-day basis. That is why we can state that it became a 'real' international crime in this century.

Piracy has always been linked with the Carribean - and it has turned up there again - but there are new hotspots, as well. In the past decade the region of the Gulf of Aden (and mainly the coast of Somalia) was the infamous one, despite the fact that the most reported attacks have been happening in Southeast Asia since the 90s. The Gulf of Guinea is also dangerous and the most violent piratical attacks happen there.

Pirates endanger the most important sea trade line all over the world. Last year, according to the Oceans Beyond Piracy foundation, they caused more than $\$ 10$ billion total cost for the economy in all endangered regions. And, of course, it threatens the lives of the seafarers, as well: according to this report, 19 of them were killed during the attacks.

It is clear that the international community has to fight piracy. There are several joint patrols in all of the regions mentioned above, but as effective they can be, they are only symptomatic treatment of the problem. The states have to deal with the criminal accountability of pirates to create a real restraining force to prevent them from committing the crime again.
\end{abstract}

\section{KEYWORDS}

Maritime piracy, international criminal law, International Criminal Court

DOI 10.14232/belv.2018.4.6

https://doi.org/10.14232/belv.2018.4.6

Cikkre való hivatkozás / How to cite this article: Pászka, Imre Ágoston (2018): Maritime Piracy as an International Crime in the 21st Century. Belvedere Meridionale vol. 30. no. 4. 96-107. pp. 
ISSN 1419-0222 (print)

ISSN 2064-5929 (online, pdf)

(Creative Commons) Nevezd meg! - Így add tovább! 4.0 (CC BY-SA 4.0)

(Creative Commons) Attribution-ShareAlike 4.0 International (CC BY-SA 4.0)

www.belvedere-meridionale.hu

\section{INTRODUCTION}

Nowadays when we hear the word 'piracy', the first thing that comes into our mind is not a 'traditional' pirate but illegal filesharing. Although many people consider piracy posed danger in the 17 th and 18 th century, they are wrong because this crime still endangers a lot of seafarers and vessels' cargo on different locations.

It was definitely the acts of Somali pirates that turned the world's attention to this threat. A little more than ten years ago their attacks were day-to-day and often appeared on the news. Their acts also led the international community to react, although modern-age piracy began to be a problem since the 1990's. This reaction is the reason we can state that piracy only became a 'real' international crime in the 21 st century.

In this paper I present the regulation and definition of piracy used by various international agreements, the reason why it is still being conducted today and its main hotspots. I also deal with the different types of conduct and the security measures which can be done by the vessel's crew. Finally, I examine the problems of accountability and the question whether it is necessary to include the crime of maritime piracy into the Rome Statute of the International Criminal Court and raise it to the level of 'the most serious crime of international concern'.

\section{Historical ReVIEW}

Maritime piracy is one of the oldest crimes in history: it is as old as maritime navigation. That is why it is not a surprise to possess evidence about serious pirate activity in the Mediterranean Sea dating back as far as the Bronze Age. ${ }^{1}$ By the way this sea was a hotspot of piracy through history, along with the Carribean, the Indian Ocean and the Southeast-Asian seas. Between 1690 and 1730 lasted an era which is often called the 'Golden Age of Piracy'. In these decades pirates attacked almost every vessel on the Carribean and managed to earn high reward and they often did it legally, thanks to the piracy licences provided by Eurpean monarchs. This era is also wellknown because pirates started to use the infamous black flag emblazoned with a skull flag. ${ }^{2}$

Retaliations ended this era. The criminal cases were always tried in front of the public and after the judges established the guiltiness, the verdicts were carried out in large numbers, thus contributing to the effect of general prevention. One glaring example: 54 pirates were hung up in the same time

\footnotetext{
${ }^{1}$ Konstam 1999. 22-23.

${ }^{2}$ Konstam 1999. 93.
} 
in 1722 in Cape Coast Castle, West Africa. As for the courts themselves: until 1700 the perpetrators were sentenced by the courts of the motherlands. After this, the colonial courts tried the cases of pirates, in accordance with the laws of the motherland. ${ }^{3}$

In the 18th century piracy once again became a standard type of warfare as monarchs used pirates to attack the enemy's merchant ships and navy. These pirates were called privateers. Strictly speaking they had state licence to attack other vessels and the loot was shared by the investors, crew and treasury. The privateers later returned to their original way of life but by this time they became more powerful and only an enormous co-operation could end their rule on the Carribean.

Nowadays the Carribeans is considered safe but pirates have not disappeared from other parts of the seas.

\section{DEFINITIONS}

When we examine the definition of piracy from both national and international perspective, we can see that many times the elements of the conduct of the perpetrator are different. Since the Bronze Age the law of people (ius gentium) have considered pirates to be the enemy of mankind (hostis humani generis) and therefore everyone could have apprehended and called them to account for their crimes. ${ }^{4}$

After World War I many international agreements (or their drafts) tried to define piracy. The first attempt occured in 1926 by the League of Nations Committee of Experts for the Progressive Codification of International Law. This definition contained the following elements: a pirate is basically a robber at sea whose actions are limited to the high sea (because otherwise it would not be under international law) and qualifies as a crime againts the security of trade at sea. ${ }^{5}$

This time the comprehensive approach was that piracy only can be committed for private ends but the London Treaty in 1930 and the Nyon Treaty in 1937 extended the definition to acts committed by warships and submarines. Nonetheless in 1956 the United Nations International Law Commission declared that maritime piracy can only be committed from a privately owned ship by private reasons. Thereafter this approach defined the dominant tendency for further regulation in international law. ${ }^{6}$

The United Nations General Assembly established the Conference on the Law of the Sea with a resolution in 1957. At this conference many agreements were passed in 1958, including the most important one, the Convention of the High Seas which codified the customary law of the sea. Article 15 of this convention contains the first definiton of piracy which was passed in an international ageement. This definiton has 5 key elements:

- the criminal act has to be violent (e. g. robbery, homicide)

- the criminal act has to be committed on high seas

- the perpetrators use a private ship or aircraft

\footnotetext{
${ }^{3}$ Legendás kalózok és a hajórablások aranykora.

${ }^{4}$ VARGA 2011a. 30-33.

${ }^{5}$ VARGA 2011a. 33.

${ }^{6}$ VARGA 2011a. 33-34.
} 
- at least two ships or aircrafts has to be involved: by which the perpetrators commit the crime and on which they commit it

- the criminal act has to be commited for private ends.

The most important source of law on the topic, the 1982 Convention of the Law of the Sea (UNCLOS) uses the same definition. A common feature of these agreements is that all of them state the high seas as the place of perpetration and also, they do not go into details about what 'private ends' mean exactly. By the way, the 'private ends' was ment to be a really important element of the definition because that is how the codificators tried to avoid using universal jurisdiction for political reasons by any state.?

A different approach was brought by International Maritime Organization (IMO) when in 1988 it helped to formulate the Convention for the Suppression of Unlawful Acts Against the Safety of Maritime Navigation (SUA). Definitions used by this convention can extend to maritime piracy and the location of perpetration to the territorial sea. ${ }^{8}$ Furthermore, the IMO General Assmebly adopted Resolution 1025(26) which made a difference between piracy and armed robbery against ships. The former's definition is basically the same as in UNCLOS. Armed robbery against ships differs from it in two ways: the number of conducts of the perpetrator have increased (e. g. looting) and the resolution specifically points out different places of perpetration ("within a State's internal waters, archipelagic waters and territorial sea'). ${ }^{9}$ According to these the main difference between piracy and armed robbery againts ships is the place of perpetration.

There is one more useful definition to examine: the International Maritime Bureau (IMB) also created one and - in my opinion - it is the most comprehensive one. It does not contain a restriction that the crime only can be committed on high seas. Furthermore, this definition rejects the element which says that two ships need to be involved. With this, it expands piracy to those - otherwise really frequent - situations when the perpetrators attack from a vehicle that does not count as a ship (e. g. raft). Also, this definiton expands the place of perpetration to ports and does not contain the element of private ends - the last one means that piracy could be committed from political ends, as well. Another interesting thing about this definition is the stating the possibility for a warship to commit piracy, as well - if it commits an act wich fits the definition of piracy. ${ }^{10}$

\section{HOTSPOTS AND THE MAIN REASONS BEHIND PIRACY}

Currently the most endangered places by pirates are the Gulf of Guinea (mainly the shores of Nigeria) and Southeast Asia (primarily the Singapore Strait, the territorial waters of Indonesia and the South China Sea). ${ }^{11}$ The infamous Gulf of Aden is much safer nowadays, thanks to the coordinated navy patrols, but Somali piracy is still a really important cornerstone of modern-day piracy, thus I will refer to it in several occasions in this paper.

\footnotetext{
${ }^{7}$ VARGA 2011a. 35-38.

${ }^{8}$ LatTMAn 2010. 68-69.

${ }^{9}$ International Maritime Organization Assembly Resolution A.1025(26).

${ }^{10}$ AMRI 2014. 7-8.

${ }^{11}$ IMB Piracy \& Armed Robbery Map 2018.
} 
In the past, piracy was committed mainly for political ends. By today this has changed and economical became the most common reason and piracy is a way of subsistence in hotspot areas. Criminal organizations and terrorrist groups take advantage of the bad financial situation of the perpetrators and corrupt bureaucrats also share in the profit. ${ }^{12}$ The last one is important because we can state that piratical activity is strong in countries where the rule of law is weak or does not even exist.

What is really necessary for commiting piracy is the favourable geographical position and within that, the proximity of trade routes. With the example of the Gulf of Aden: the European Union concludes $95 \%$ of its sea trade and $20 \%$ of its energy import through this route. Furthermore, the safety of these waters is a common interest of the United States, China and Russia, as well. ${ }^{13}$ The situation is really similar in the Gulf of Guinea, too: this region is rich in petroleum and $40 \%$ of the EU's and $29 \%$ of the US' consumption is coming from here. ${ }^{14}$ Furthermore, the Western African countries are rich in other natural treasures (e. g. gold, coca, diamonds), thus the trade routes are busy and this creates more chance for the pirates to attack, as well. ${ }^{15}$

We have to say a few words about Somalia. As I mentioned, this is the most infamous hotspot of modern piracy but the coordinated navy patrols managed to make the Gulf of Aden safer. Although, shipping through those trade routes is still dangerous, less and less pirate attacks happened in the past few years. By today, Nigeria has taken the place of Somalia as an infamous piracy hotspot. These pirates more often kidnap seafarers and demand a ransom, moreover an IMB report from 2016 pointed out that this is the pirates' primary objective now. This report also remarked that a really notable feature of the attacks happening here is that they are more violent than attacks at other hotspots. ${ }^{16}$

However most of the registered attacks happen in Southeast Asia. These are similar to the Somalis in a way that the perpetrators attack every vessel from fishing ships to oil tankers. ${ }^{17}$ The special feature of this region is its geographical conditions which are incredibly useful for pirates: the vessels have to cross narrow straits and archipelagic waters, thus bigger ships cannot hold the 18 knots speed which was stated in international directives as the safe velocity against pirate attacks. ${ }^{18}$

Finally, there is a familiar hotspot where piracy became a threat again in the past few years. This is the Carribean and Latin America. In 2017, Oceans Beyond Piracy ${ }^{19}$ recorded 71 piratical incidents, which is a 163 percent increase over 2016. Pirates here usually attack yachts, not merchant vessels. ${ }^{20}$

\footnotetext{
${ }^{12}$ Harkai 2015. 184.

${ }^{13}$ NAGY 2014.

${ }^{14}$ Defining piracy in the Gulf of Guinea.

${ }^{15}$ Fiorelli 2014. 9-10.

${ }^{16}$ International Maritime Bureau Report (25 July 2016).

${ }^{17}$ KLemensits 2016.

${ }_{18} 5$ Reasons Why Southeast Asian Piracy is Here to Stay.

${ }^{19}$ As a program of One Earth Future foundation, Oceans Beyond Piracy is a response to maritime piracy through e. g. "developing public-private partnerships to promote long-term solutions at sea and ashore".

${ }^{20}$ Piracy and Armed Robbery against Ships in Latin America and the Caribbean 2017.
} 


\section{TYPES OF ATTACK AND PERPETRATION AND WHAT THE CREW CAN DO}

Robert Beckman distinguished the different types of attacks based on four core elements:

- The weapons used by the pirates (because no pirate commits the crime unarmed).

- The seriousness of violence used by the pirates on crew members (from assault to homicide).

- The value of the misappropriated valuables (including the ransom for the crew, as well).

- The level of danger posed to maritime transport. This means that if the pirates attack in a strait, which is narrower, then they endanger not only the attacked ship and its crew but the rest of the ships travelling through that strait.

Although pirate attacks can be different in smaller details but we can distinguish three typical classes of them:

- Hit-and-run: the perpetrators attack the ship, rob the crew and leave. This only takes a few minutes.

- The pirates not only rob the crew but also the ship's cargo. These attacks usually happen between 1 a.m. and 6 a.m. when the crew is sleeping and the pirates almost always use modern technology for the hijacking.

- The 'phantom ship': this is the most sophisticated one. The pirates buy or somehow acquire a ship. They rename it, repaint it and reflag it. After that they find a shipper who is short on time to move his cargo. They offer him their 'phantom ship' as carrier and simply sail off with the cargo. ${ }^{22}$

The last one shows us the best how dangerous the pirate attacks can be. These kind of operations need weeks of preparation to execute.

The various international organizations passed several recommendations which can help the crew to prevent the attacks. These documents recommend them to travel on internationally recognized maritime routes, increase the speed on dangerous waters, illuminate the vessel at night and not to stop in case of an attack. ${ }^{23}$

But the most effective way to defend the ships is to hire a private armed security service. They can defend against an attack even when navy patrols are far away. Another, although somewhat radical method is the 'Q-ship'. This is a fortified ship with more effective defence and weapon system which appears to be a defenceless merchant vessel and thus a fine target for pirates, luring them into an attack and destroying the pirate vessel outright. This is actually a known method in warfare. But piracy is not a war situation. The goal is to bring the perpetrators to justice, not to destroy them. That is why this method gives reason for concern. ${ }^{24}$

\footnotetext{
${ }^{21}$ VARGA 2011b. 43-44.

${ }^{22}$ Types of pirate attacks.

${ }^{23}$ VARga 2011b. 45.

${ }^{24}$ VARGA 2011b. 51-53.
} 


\section{Criminal accountability}

The international community is trying to suppress piracy with the effective assistance of international organizations. The United Nations Security Council has passed several resolutions regarding this crime and the maritime organizations (IMO, IMB) are making an effort to help seafarers, as well. For example, IMO is operating the Piracy Reporting Centre which is a database, updated every 24 hours, where captains can report suspicious vessels and attacks. We have to mention the United Nations Office on Drugs and Crime (UNODC) which organizes special trainings for states along the Gulf of Aden to strenghten their "prosecution capacity". This means that UNODC helps the police, judges and prosecutors to deal piracy cases. This program also includes the development of the penitentiary system of Somalia. ${ }^{25}$

In addition, there are ongoing military operations at the hotspots which are including coordinated navy patrols. We have to point out the NATO's Ocean Shield Operation which has helped to deter and disrupt pirate attacks in the Gulf of Aden and the Horn of Africa since 2008. ${ }^{26}$ Thanks to this operation, the number of attacks are greatly decreased (only 2 attempted attacks in 2018 until September according to IMB's Live Piracy Map) ${ }^{27}$ But no matter how successful these operations are in the short term, they are only a symptomatic treatment of the problem and to succeed in the long term, the most important is to deal with the shortcomings of criminal acountability.

As for the legislative nature of maritime piracy: according to customary international law, this is the oldest crime to which universal jurisdiction applies, meaning that every state may use its own domestic law to punish those combatting piracy regardless of the pirates' nationality or where the attack took place. ${ }^{28}$ But bringing pirates to justice is difficult because many times the countries interested in repressing piracy did not conduct the criminal procedure, but they released the perpetrators. There is a simple explanation for this hesitation: these countries simply do not want to bear the costs of the transportaion of physical evidence and witnesses to the place of the trial. Furthermore, the coordination of jurisdiction also has its difficulties because the crime of piracy can involve several states, namely the state to which the victims are nationals, the state to which the pirates' ship belong to or the state to which the owners of the cargo are nationals. ${ }^{29}$

Again, we have to mention Somalia, as a cornerstone of modern piracy. The UN declared Somalia a failed state. It does not have a real government which has control over the full territory of the state, thus it cannot enforce the execution of the law either. Furhermore, in Somalia, the procedural guarantees and the right to a fair trial are not provided during the criminal procedure which are well-known and demanded by most of the countries. Nonetheless the states interested in repressing piracy are urging that trials should take place in the region where the piratical act happened. ${ }^{30}$

\footnotetext{
${ }^{25}$ Hodkingson 2013. 153-154.

${ }^{26}$ Operation Ocean Shield.

${ }^{27}$ IMB Piracy \& Armed Robbery Map 2018.

${ }^{28}$ DutTon 2010. 203-204.

${ }^{29}$ Kalra 2011. 3.

${ }^{30}$ VARGA 2011b. 36-37.
} 
In a few scholars' opinion, the problem of piracy has to be solved regionnaly, thus it is necessary to establish regional courts. They say that local judges would know regional customs better, so the procedures would be more effective. Furthermore, it could increase the anti-piracy operations' efficiency if the coordinating parties would know the exact procedural rules applied by this regional court (e. g. what evidence it accepts). In Diana Chang's opinion, a regional court could create the conditions of a unified system which could get rid of the contradictions of different domestic laws, including the difficulties that come from the lack of a generally accepted piracy definition. Thus, they do not have to rely on whether every counry in the region has an appropriate piracy definiton or punish this crime in its penal code. Furhthermore, she believes that the framework of the coordination has already been created in every country of the region. ${ }^{31}$

States along the Gulf of Aden indeed signed an agreement which could be a fine basic to establish a court like that: the Djibouti Code of Conduct which was passed in 2009 and has 20 contracting parties. The coordination stated in the Code includes the investigation of piracy and armed robbery against ships and the arrest and charge of the suspects. The state parties also ensure that their penal codes would punish these crimes and that they would excercise their jurisdiction during the criminal procedure. ${ }^{32}$ This indeed a good starting-point and a leading example for other regions.

Here, we have to mention Somalia again because it is a good example for the international community's activity. The UN Secretary General presented a report to the Security Council about the accountability of Somali pirates in May 2010 which contained several possible solutions - all of which would have been realized with the help of the UN. In this article I will only present a few of these. One suggested the establishment of a Somali court which would have its seat in another country of the region. This could create the conditions for the operation of the court that are not possible in Somalia because of its failed state status. The court would excercise Somali jurisdiction on the territory of an other state. The problem with this proposal is that it would be hard to find a state which has the will and capability to receive a foreign court. Also, the Somali anti-piracy laws and judicature system give reasons for concern, thus it might not worth the energy and fundings to establish this court.

Another suggestion would be the establishment of a special divison of court in the jurisdiction of a state in the region. The judges would be selected by the UN. For that, it would be necessary to change the domestic law of the home country because divisional adjudication is unknown in the region. The report also suggests the establishment of an international court in two different ways. The first would be the establishment of a court based on an agreement between the UN and the region's countries. The majority of the judges would be selected by the UN but the international pattern would be beneficial for the home country. The second option suggests that the UN Security Council should establish an international court acting under Chapter VII of the Charter of the United Nations. All of the judges, prosecutors and staff members would be selected by the UN, in fact it might not be seated in the region. The advantage of this court is that UN members have to oblige the Security Council's resolutions. But both of the options have the same disadvantage: they are moneyand time-consuming and the problem of accountability needs a solution as soon as possible. ${ }^{33}$

\footnotetext{
${ }^{31}$ Chang 2010. 285-286.

${ }^{32}$ Djibouti Code of Conduct.

${ }^{33}$ VARgA 2011b. 40-42.

${ }^{34}$ Kamal-Deen 2015. 108-109.
} 
Although this report has referred specifically to Somalia, generally we can state that the regions endangered by piracy do not have a proper legal system supplemented by judiciary, thus they cannot provide the accountability of the perpetrators on an expected level. Even though the Western African states' justice systems are on a higher level than the Somali one, only Liberia and Togo have an up-to-date anti-piracy law. The lack of proper laws comes from the fact that the states along the Gulf of Guinea do not have the necessary starting-point. For example Cameroon, Angola and Gabon are not state parties of the above-mentioned SUA Convention, Cote d'Ivore and Nigeria have not implemented it to their domestic law. ${ }^{34}$ The situation is slightly better in Southeast-Asia because several pirates have been charged in the past few years. But Indonesia and Malaysia, which are two of the most endangered countries, are also not parties of the Convention, ${ }^{35}$ and without that it is hard to provide the neceassary legal framework.

In my opinion, it is not the right way to spend serious amount of money on establishing new courts, whether they will be regional or international. This would be really time-consuming and the seriousness of the situation requires actions as soon as possible. I believe that the best solution would be to involve of an already existing court - the International Criminal Court (ICC). According the Statute of Rome, the ICC has jurisdiction over 'the most serious crimes of concern to the international community as a whole', namely genocide, crimes against humanity, war crimes and agression.

I think that piracy causes so much trouble for the international community that it really have think think about expanding the jurisdiction of ICC. It causes grave damage to global economy, in a not so extreme situation, it can cause a natural disaster (e. g. an attacked tanker damages and its cargo flows into the sea) and endangers human lives, as well. Furthermore, pirates often commit crimes which are on the list of conducts of crimes againts humanity (e. g. homicide and torture). ${ }^{36}$ In my opinion, these arguments show us the necessarity of reconsidering the jurisdiction of ICC. Also, under Article 121 of the Statute, an amendment can be submitted at any time by any state, thus negotiations could be started easily.

Article 17 declares that every state has to investigate and prosecute international crimes and the ICC only steps in if the state, which has jurisdiction over the case, is unwilling or unable to conduct the procedure. This complementary role means that the Court does not have to trial every case. Another argument in favor of the ICC is that its regionality could be achieved because Article 3 of the Statute states that it 'may sit elsewhere, whenever it considers it desirable, as provided in this Statute'. This way it would not be necessary to establish ad hoc tribunals like ICTY or ICTR. ${ }^{37}$ On one hand the costs of moving the required personnel would be really high, but on the other hand the costs of transporting witnesses and other evidence would decrease. Despite all these, it is unnecesary to move the Court or one of its chambers because some extra fundings could cover the extra costs mentioned above.

There are also several jurisdictional issues to discuss. Article 12 of the Statute declares that the ICC can only excercise its jurisdiction (along with the fact that a State Party is unwilling or unable to do so) when the crime was committed on a State Party's territory or by a national of a State Party. But how can the ICC obtain its jurisdiction, for example, over an Indonesian pirate in Malaysian territorial waters when non of these two states are State Parties of the Rome Statute?

\footnotetext{
${ }^{35}$ International Maritime Organisation. Status.

${ }^{36}$ DutTon 2010. 233-234.

${ }^{37}$ Dutton 2010. 233.
} 
There is no perfect solution for this problem, but any proposal that could increase the number of piracy cases would be welcomed. The first probable solution would be to consider the flag state of the attacked ship. If it is a State Party, the Court could excercise its jurisdiction over the perpetrators. Another solution would be the application of the principle of passive personality jurisdiction. If the victim is a national of a State Party, this state could refer this situation to the ICC (which is allowed by Article 14). Finally, the UN Security Council, acting under Chapter VII of the UN Charter, could also refer a situation to the ICC to excercise its jurisdiction. This way the Court can investigate and prosecute crimes that were not committed by a State Party's national or within the territory of a State Party to the Rome Statute. However, the referral like this would be problematic in relation to piratical acts committed on territorial waters (e. g. the Malacca Strait or South China Sea) because the littoral states of these waters are not parties to the Statute and they might see this Security Council resolution as a restriction of their jurisdiction. Also, it is certain that China would excercise its right to veto, thus the resolution would not be adopted. ${ }^{38}$

\section{Conclusion}

Maritime piracy is a serious threat to international peace and security. Pirates endager the lives of seafarers and the safety of the world's most important sea trade lines every day. Although, joint patrols and navy coorporation could suppress the attacks in Somalia and the Malacca Strait but that is not enough to deal this problem. The states interested in the fight against piracy have to make sure that a real restraining force is in their hands, which is criminal accountability.

We do not know yet how the international community will deal with the criminal accountability of pirates. But the situation requires a solution as soon as possible and pirates have to face trials where they can be sentenced. This would mean the real solution because the coordinated navy patrols cannot hold pirates back forever. A proper international legal framework is also not provided for the accountability, just for their capture. The best solution would be the including piracy within the jurisdiction of the International Criminal Court. It is useless to fund the creation of a new court, because the ICC can deal with piracy cases, if the necessary resources are provided.

\section{BIBLIOGRAPHY}

Amri, Ahmad (2014): Southeast Asia's Maritime Piracy: Challanges, Legal Instruments and a Way Forward. Australian Journal of Maritime and Ocean Affairs vol 6. issue 3. 154-169. http://ro.uow.edu.au/ cgi/viewcontent.cgi?article=2662\&context=lhapapers (Accessed: 30. 08. 2018.) Chang, Diana (2010): Piracy Laws and the Effective Prosecution of Pirates. Boston College International and Comparative Law Review volume 33. issue 2. https:/lawdigitalcommons.bc.edu/cgi/ viewcontent.cgi?referer $=\&$ httpsredir $=1 \&$ article $=1012 \&$ context $=\mathrm{iclr}$ (Accessed: 04. 09. 2018.)

\footnotetext{
${ }^{38}$ O’BRIEN (2014) 100-101.
} 
Dutton, Yvonne M. (2010): Bringing Pirates to Justice: A Case for Including Piracy within the Jurisdiction of the International Criminal Court. Chicago Journal of International Law vol. 11. no. 1. http://chicagounbound.uchicago.edu/cgi/viewcontent.cgi?article=1341\&context=cjil (Accessed: 04. 09. 2018.)

Fiorelli, MatThew (2014): Piracy in Africa: The Case of the Gulf of Guinea. KAIPTC Occasional Paper No. 37. https://www.africaportal.org/documents/12359/Fiorelli-KAIPTC-Occasional-Paper2014.pdf (Accessed: 31. 08. 2018.)

HARKAI IsTVÁN (2015): A kalózkodás nemzetközi jogi kérdései és egy bukott állam felelőssége. Szakmai Szemle 1. sz. 179-195. http://knbsz.gov.hu/hu/letoltes/szsz/2015_1_szam.pdf (Accessed: 31. 08. 2018.)

Hodkingson, Sandra L. (2013): Current Trends in Global Piracy: Can Somalia's Successes Help Combat Piracy in the Gulf of Guinea and Elsewhere? Case Western Reserve Journal of International Law vol. 46. issue 1. 145-160. http://scholarlycommons.law.case.edu/cgi/ viewcontent.cgi?article $=1033 \&$ context $=$ jil (Accessed: 04. 09. 2018.)

KAlRA, Kush (2011): Is International Law Effective Against Pirates? Lessons from Somalia. International Bar Notes. https://www.ibanet.org/Document/Default.aspx?DocumentUid= D063B524-A38F-4E22-87C8-C9A38742EB74 (Accessed: 04. 09. 2018.)

Kamal-Deen, Ali (2015): The Anathomy of Gulf of Guinea Piracy. Naval War College Review vol 68. issue 1.93-118. http://digital-commons.usnwc.edu/cgi/viewcontent.cgi?article= 1183\&context=nwc-review (Accessed: 08. 09. 2018.)

Konstam, Angus (1999): Kalózok. Gulliver Könyvkiadó, Budapest, 1999.

LATTMAN TAMÁs (2010): A szomáliai kalózkodás kérdése a nemzetközi jogban és azon túl. Nemzet és Biztonság 3. évf. 9. sz. 66-75. http://www.nemzetesbiztonsag.hu/cikkek/lattmann_tamasa_szomaliai_kalozkodas_kerdese_a_nemzetkozi_jogban_es_azon_tul_.pdf (Accessed: 30. 08. 2018.)

O’Brien, Melanie (2014): Where Security Meets Justice: Prosecuting Maritime Piracy in the International Criminal Court. Asian Journal of International Law vol. 4. issue 1.

VArga, Attila Ferenc (2011a): Kísérletek és eredmények a kalózkodás definíciójának meghatározásában. Hadtudományi Szemle 4. évf. 1. sz. 30-43. http://archiv.uni-nke.hu/downloads/ kutatas/folyoiratok/hadtudomanyi_szemle/szamok/2011/2011_1/2011_1_br_varga_attila_30_43.pdf (Accessed: 30. 08. 2018.)

VArga Attila Ferenc (2011b): Nemzetközi küzdelem a szomáliai kalózkodással szemben. Hadtudomány 21. évf. 1-2. sz. http://mhtt.eu/hadtudomany/2011/2011_elektronikus/2011_e_14.pdf (Accessed: 03. 09. 2018.)

\section{Other Sources}

5 Reasons Why Southeast Asian Piracy is Here to Stay. Gcaptain. 2014. https:/gcaptain.com/ 5-reasons-southeast-asian-piracy-stay (Accessed: 31. 08. 2018.) 
Defining piracy in the Gulf of Guinea. http://www.irinnews.org/news/2012/12/10/defining-piracygulf-guinea (Accessed: 31. 08. 2018.)

Djibouti Code of Conduct. http://www.imo.org/en/OurWork/security/piu/Pages/DCoC.aspx (Accessed: 06. 09. 2018.)

International Maritime Organization Assembly Resolution A.1025(26). http://www.imo.org/en/ OurWork/Security/PiracyArmedRobbery/Guidance/Documents/A.1025.pdf\#search=resolution\%201025

KLEMENSITS PÉTER (2016): A kalózkodás problémája Délkelet-Ázsiában a 21. században. PAGEO. Geopolitikai Kutatóintézet. http://www.geopolitika.hu/hu/2016/11/18/a-kalozkodas-problemajadelkelet-azsiaban-a-21-szazadban/ (Accessed: 31. 08. 2018.)

International Maritime Bureau Report (25 July 2016). http://icc.se/wp-content/uploads/2016/07/ IMB-Q2-press-release-2016-_-250716.pdf (Accessed: 31. 08. 2018.)

International Maritime Organization Assembly Resolution A.1025(26). http://www.imo.org/en/ OurWork/Security/PiracyArmedRobbery/Guidance/Documents/A.1025.pdf\#search=resolutio n\%201025 (Accessed: 30. 08. 2018.

International Maritime Organisation. Status. http:/www.imo.org/en/About/Conventions/ StatusOfConventions/Documents/status-X.xlsx Accessed: 08. 09. 2018.)

IMB Piracy \& Armed Robbery Map 2018. https://www.icc-ccs.org/piracy-reporting-centre/livepiracy-map (Accessed: 31 08. 2018.)

Legendás kalózok és a hajórablások aranykora. Múltkor.hu https://mult-kor.hu/20051029_ legendas_kalozok_es_a_hajorablasok_aranykora?pIdx=2 (Accessed: 29. 08. 2018.)

NAGY ZsANETT MÁRIA (2014): A kalózkodás modern valósága. Arsboni. http:/arsboni.hu/kalozkodas/ (Accessed: 31. 08. 2018.)

Operation Ocean Shield. NATO Allied Maritime Command. https://mc.nato.int/missions/operationocean-shield.aspx (Accessed: 04. 09. 2018.)

Piracy and Armed Robbery against Ships in Latin America and the Caribbean 2017. http://oceansbeyondpiracy.org/reports/sop/latin-america (Accessed: 05. 09. 2018.)

Types of pirate attacks. http://www.cargolaw.com/presentations_pirates.html\#type_attacks (Accessed: 03. 09. 2018.) 